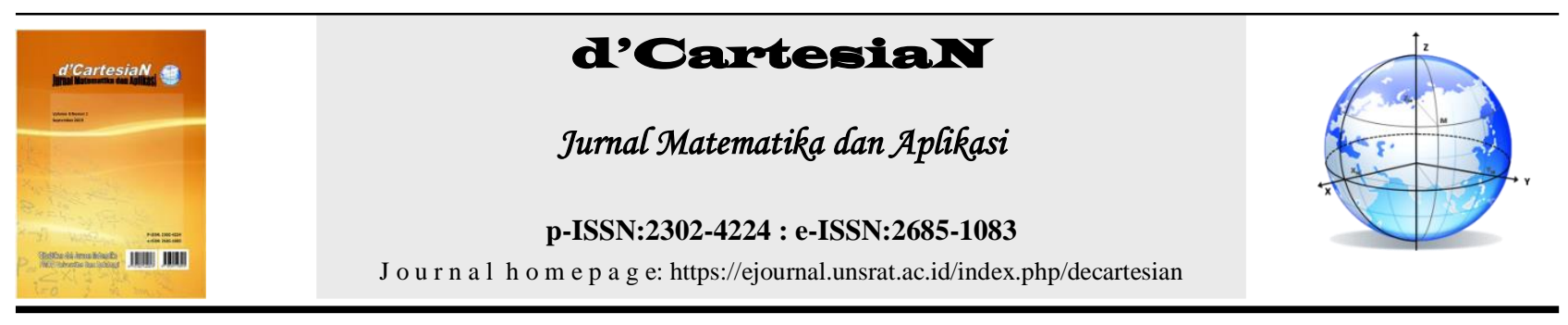

\title{
Black-Scholes Model in Determining European Option Prices on Netflix,Inc.
}

\author{
Desty Adelia Tambingon", Jullia Titaley ${ }^{1}$, Tohap Manurung ${ }^{1^{*}}$ \\ ${ }^{1}$ Mathematics Department-Faculty of Mathematics and Natural Sciences-Universitas Sam Ratulangi Manado, Indonesia \\ *Corressponding author : $\underline{\text { Tohapm@unsrat.ac.id }}$
}

\begin{abstract}
A B S T RA C T
Research has been conducted to compare the prices of European option on the Yahoo Finance website with prices obtained from the Black-Scholes model (theoretical price). Data was taken on January 31, 2019 which included the daily share price of Netflix, Inc. (NFLX) on February 14, 2018 - January 31, 2019 to obtain volatility, and NFLX options data due on January 17, 2020. Options with prices lower than theoretical prices are said to be underpriced, so the decision taken is to buy the options. Whereas options with prices higher than theoretical prices are said to be overpriced, so it has to be reconsidered. The proportion of the underpriced call options for the total number of call options is $77.7778 \%$, while the proportion of the underpriced put options for the total number of put options is $38.5714 \%$.
\end{abstract}

\section{ARTICLE INFO}

Accepted : 20 June 2019

Accepted after revision : 23 July 2019

Available online : 25 July 2019

\section{Keywords:}

Options

Call

Put

European Options

Black-Scholes

\begin{abstract}
A B S T RA K
Telah dilakukan penelitian untuk membandingkan harga opsi tipe Eropa pada website Yahoo Finance dengan harga yang diperoleh dari model Black-Scholes (harga teoretis). Data diambil pada 31 Januari 2019 yang meliputi harga saham harian Netflix, Inc. (NFLX) pada 14 Februari 2018 - 31 Januari 2019 untuk memperoleh volatilitas, dan data opsi NFLX yang jatuh tempo pada 17 Januari 2020. Opsi dengan harga lebih rendah dari harga teoretis dikatakan underpriced, sehingga keputusan yang diambil adalah membeli opsi tersebut. Sedangkan opsi dengan harga lebih tinggi dari harga teoretis dikatakan overpriced, sehingga perlu dilakukan pertimbangan kembali. Proporsi jumlah opsi beli yang underpriced terhadap jumlah keseluruhan opsi beli sebesar 77,7778\%, sedangkan proporsi jumlah opsi jual yang underpriced terhadap jumlah keseluruhan opsi jual sebesar 38,5714\%.
\end{abstract}

\section{INFO ARTIKEL}

Diterima : 20 Juni 2019

Diterima setelah revisi : 23 Juli 2019

Tersedia online : 25 Juli 2019

\section{Kata Kunci: \\ Opsi \\ Call \\ Put \\ Tipe Eropa \\ Black-Scholes}

\section{INTRODUCTION}

The Capital Market is an activity concerned with public offering and securities trading, public companies related to securities issued, as well as institutions and professions relating to securities [1]. The principal assets that can be traded on the capital market include stocks, bonds, stock indices, bond indices, currencies, interest rates, and other financial instruments. The development of asset buying and selling transactions that are increasingly rapid makes investors want an investment that can minimize the existence of financial risks. This is the background for the introduction of derivative instruments.

Derivatives are contracts or agreements whose value or profit opportunities are related to the performance of underlying assets [2]. Options are one of the derivative products used by market players as instruments for the purpose of obtaining profits or for protecting their assets from falling prices and avoiding greater losses. Options are known for a long time, but are officially traded on the capital market in October 1973 on the Chicago Board of Options Exchange (CBOE). In Indonesia, these are known as KOS (Kontrak Opsi Saham). KOS was first traded on the Indonesia Stock Exchange (IDX) in 2004. But IDX stopped its options trading in 2008.

KOS is an effect that contains a call option or a put option on the shares of a listed company that becomes the underlying stock in KOS series trading with a certain amount and price of execution and is valid for a certain period. The execution price is the price set by the exchange for each KOS series as a reference in execution. American type option holders can execute their rights at any time until the due date, while European type options only provide an opportunity for option holders to execute their rights at maturity [3].

At present there are many methods to determine option prices. This will continue to grow because it is very helpful for investors in determining their investment decisions on options. Determining the price of an option is not easy. There are several ways to determine the price of an option contract, including the Binomial Option Pricing Model (BOPM), the Black-Scholes model, Monte Carlo Simulation, etc. [4].

One model in the analytical method commonly used to calculate option prices is the Black-Scholes model. This model was developed by Fisher Black and Myron Scholes in 1973 to determine European type option prices 
assuming no dividend payments, no transaction costs, constant risk-free interest rates, and changes in stock prices following a random pattern [5]. Referring to several previous studies [6] and [7], the Black-Scholes method is an effective method for determining option prices.

A company must meet certain criteria before stock options as derivatives of their own stock instruments can be traded on the stock. One of the conditions that must be fulfilled by a company to trade its stock options is to register the shares on the NYSE, AMEX or NASDAQ (US Market) exchange [2]. Netflix (NASDAQ: NFLX) is one of the first and largest online DVD rentals, offering flat rate DVD rentals by mail to customers in the United States. In 2017, revenue jumped $32.41 \%$ to 11.69 billion US dollars and net income was up $199.41 \%$ to 558.93 million US dollars. Netflix, Inc. is also one of the companies included in the NASDAQ-100 stock market index, which is an index consisting of the 100 largest non-financial companies listed on the NASDAQ. Therefore, Netflix shares can be used as an underlying asset for trading option in order to provide a large profit.

In this research, the author uses the Black-Scholes model to determine the price of European call and put options of Netflix, Inc. with a closing price of 242 working days with a risk-free interest rate on Treasury Bill Rates issued by the United States government. The results obtained are compared with the price of options sold on the stock exchange.

\section{Derivatives}

Derivative instruments can be defined as financial instruments in the form of agreements or contracts between two parties where the profit is related to the price of the underlying asset [8]. These underlying assets can be stocks, bonds, stock indices, bond indexes, currencies (currency), interest rates and other financial instruments [9]. Widely known derivative instruments include future contracts, forward contracts, swaps, and options.

\section{Options}

Option is a right, not an obligation, to buy or sell an asset at a certain price and at a predetermined time. The party that gets the right is called an option buyer or also called the option holder, while the party that sells the option and must be responsible for the decision of the option buyer when the option will be used is called the option writer. The option deadline is called the expiration date, and the asset price agreed upon by the writer and buyer is called the strike price or exercise price [10].

\section{Types of Options}

Options are divided into several types, depending on the used point of view. Based on the way or place the option is traded, the option is divided into three groups [2], namely:

1. Options traded on the stock (listed options).

2. Options that are traded between two parties and are often traded off the counter (Over the Counter-OTC)

3. Employee stock option, which is an option issued by the company as compensation or bonus for employees.

Based on the exercise method, options are divided into two types, namely American options and European options. The American options provide an opportunity for option holders to exercise their rights at any time until the due date, while the European options only provide an opportunity for option holders to exercise their rights when the time is due.

\section{Option Components}

Option components consist of [11]:

1. An official contract, where there are two parties that agree to make a contract that cannot be unilaterally canceled.

2. Option rights (without obligation), are buying rights called call options and selling rights called put options.

3. Underlying assets, are assets underlying the derivatives that are traded. These assets can take the form of various types, including stocks, futures, currencies, bonds, commodities and others. The underlying assets used in this study are stocks.

4. Strike price, is the price at which the assets intended in the official contract are traded.

5. Expiration date, is the last day on which an option can be executed. Each option has a life span or validity period, starting from 1 day up to a maximum of 3 years.

\section{Call Option}

Call option is a contract where an option buyer (taker call) is given the right by an option seller (writer call) to buy a reference stock in a certain amount and at the agreed price (strike price) and is valid for a certain period of time. Taker call has the right to execute the purchase right or not, until the due date [2].

The call option seller (writer), is obliged to sell the underlying stock in the amount and at the agreed price (strike price) to the call option buyer (taker) because he has received the call premium (call option price) from the call option buyer [3].

Based on the understanding of call option, the intrinstic value is the difference between the stock price and the strike price. The mathematical form of intrinsic value for European type buying options can be expressed as

where,

$$
f_{c}=\max \left(S_{T}-K, 0\right)
$$

$f_{c}=$ call option payoff value

$S_{T}=$ asset price at maturity

$K=$ strike price

From the equation above, call option can be divided into three types, namely:

1. Call option is said to be out of the money, if the stock price is lower than the strike price and this option will be zero.

2. Call option is said to be in the money, if the stock price is higher than the strike price and is positive.

3. Call option is said to be at the money, if the stock price is equal to the strike price.

\section{Put Option}

Put Option is a contract in which the option buyer (put taker) is given the right by the option seller (put writer) to sell the reference stock in a certain amount and price (strike price) and is valid at a certain time. Taker has the full right to execute his selling rights or not, up to the maturity date [2].

The seller of the put option, is obliged to buy the underlying stock in the amount and the strike price referred to the buyer because he has received the put premium (put option price) from the put option buyer [3].

Based on the understanding of selling options, intrinsic value is a reduction between strike prices and 
stock prices. The form of mathematical equation intrinsic value of selling options can be expressed as

$$
f_{p}=\max \left(K-S_{T}, 0\right)
$$

where,

$f_{p}=$ put option payoff value

$S_{T}=$ asset price at maturity

$K=$ strike price

From the equation above the put option can be divided into three types, namely,

1. The put option is said to be out of the money, if the stock price is higher than the strike price and this option will be zero.

2. The put option is said to be in the money, if the stock price is lower than the strike price and is positive.

3. The put option is said to be at the money, if the share price is equal to the strike price.

\section{Stock Option Premiums}

An option premium consists of intrinsic value and time value. Intrinsic value is the real value already contained in the premium of an option. Time value is also known as extrinsic value. The value of time will decrease every day and at the time of maturity the time value will be zero, which is usually called time decay. In other words, the time value of an option is directly related to how much time an option has before the time is due [11].

The time value of an option is influenced by the remaining life time of the option until maturity, volatility, liquidity, interest rate and market sentiment. Volatility is a measure that states how likely stock prices can move up or down in a given period. Volatility greatly influences the time value of an option which ultimately affects the premium value of the option. Liquidity is a measure of how easily an asset is converted into cash without significant impairment. An increase in interest rates will push the call option premium to rise, while dividends will reduce the value of the call option premium. Market sentiment is reflected in supply and demand. The higher the demand, the higher the call option premium [11].

\section{Volatility}

Volatility is a measure of changes in asset prices regardless of direction [12]. To estimate the volatility of an stock price empirically, stock prices are usually observed at certain time intervals (for example every day, week or month). Define [5]:

$n+1:$ Number of observations

$S_{t} \quad$ : The stock price at the end of the $t$-interval, with $t$ $=0.1, \ldots, \mathrm{n}$

$\tau \quad:$ Length of time interval in units of years.

Continuously compounded return is given by [13]:

$$
r_{t}=\ln \left(\frac{s_{t}}{s_{t-1}}\right) \quad \text { for } t=1,2, \ldots, n
$$
given by

The standard deviation of $r_{t}$, symbolized by $s$, is

where $\overline{r_{t}}$ is the mean of $r_{t}$

$$
s=\sqrt{\frac{1}{n-1} \sum_{t=1}^{n}\left(r_{t}-\overline{r_{t}}\right)^{2}}
$$

The standard deviation of $r_{t}$ is $\sigma \sqrt{\tau}$, so $s$ is the estimate of $\sigma \sqrt{\tau}$. So, $\sigma$ can be estimated as $\hat{\sigma}$, where

$$
\hat{\sigma}=\frac{s}{\sqrt{\tau}}
$$

The standard error of this estimate is

$$
S E=\hat{\sigma} / \sqrt{2 n}
$$

Choosing a suitable value for $\mathrm{n}$ is not easy. More data generally increases the accuracy of estimates, but $\sigma$ changes with time and data that is too old can be irrelevant in predicting future volatility. The decision that can be made is to use the daily closing price in the last 90 to 180 days. The value of $n$ is made equal to the number of days where volatility will be applied [5]

\section{Black-Scholes Model}

In the early 1970s, Fischer Black, Myron Scholes, and Robert Merton made a big breakthrough in pricing European type options. This discovery carried Robert Merton and Myron Scholes receive a Nobel in economics in 1997. Black-Scholes is a model used to determine the price of options that have been widely accepted in the financial community. This model is of limited use because it can only be used for European type option pricing that is run only at the expiration date, while this model does not apply to American type options, because the American type option can be run at any time until the expiration date.

Assume the stock price process follows the Geometric Brownian Motion model:

$$
d S=\mu S d t+\sigma S d z
$$

where $\mathrm{dS}$ is the change in stock prices at time intervals dt, $\mu$ is a constant parameter that states the average growth rate of stock prices, $\sigma$ is the stock price volatility, and $\mathrm{dz}$ is the change in variable $\mathrm{z}$ at the time interval dt. $\mathrm{z}$ is a random variable that represents a combination of all random effects.

Using Lemma Itô, obtained:

$$
\frac{\partial f}{\partial t}+r \frac{\partial f}{\partial S} S+\frac{1}{2} \frac{\partial^{2} f}{\partial S^{2}} \sigma^{2} S^{2}=r f
$$

where $f$ is the price of derivative products and $r$ is the riskfree interest rate. The equation above is the Black Scholes differential equation (PD). This PD has various solutions, depending on the types of derivatives that can be defined in $\mathrm{S}$ as basic variables. The solution depends on the boundary condition of each derivative. In European call options, the boundary conditions used are

$$
f=\max \left(S_{T}-K, 0\right)
$$

This means that the execution will be carried out if the stock price at maturity exceeds the strike price. As for European put options, the boundary conditions used are

$$
f=\max \left(K-S_{T}, 0\right)
$$

That is, the execution will be carried out if the strike price exceeds the share price at maturity.

By completing PD with the above limitation function, the European call option price (c) and put option (p) are obtained as follows

$$
\begin{gathered}
c=S_{0} N\left(d_{1}\right)-K e^{-r T} N\left(d_{2}\right) \\
p=K e^{-r T} N\left(-d_{2}\right)-S_{0} N\left(-d_{1}\right) \\
d_{1}=\frac{\ln \left[\frac{S_{0}}{K}\right]+\left(r+\frac{\sigma^{2}}{2}\right) T}{\sigma \sqrt{T}} \\
d_{2}=\frac{\ln \left[\frac{S_{0}}{K}\right]+\left(r-\frac{\sigma^{2}}{2}\right) T}{\sigma \sqrt{T}}
\end{gathered}
$$

where

$S_{0}$ : initial stock price

$K$ : strike price

$r$ : risk-free interest rates

$T$ : option life span (units of year)

$\sigma$ : annual volatility of stock prices

$N(x)$ expresses the cumulative probability distribution function for the standard normal distribution. In other words, $N(x)$ is the probability of a variable with a standard normal distribution, $\phi$ (o.1), will be less than $x[5]$.

\section{Netflix, Inc.}

Netflix, Inc. is a company that provides the world's leading internet television network with more than 117 million streaming membership in more than 190 countries enjoying more than 140 million hours of TV 
shows and films per day, including original series, documentaries and feature films. The company was founded by Reed Hastings and Marc Randolph in Scotts Valley, California in 1997. Currently, Netflix, Inc. headquartered in Los Gatos, California. Netflix common shares are traded on the NASDAQ Global Select Market with the symbol "NFLX". Netflix paid members increased by 29 million from the beginning of 2018 to 139 million. This has an impact on Netflix's annual income which increased 35\% in 2018 to 16 billion US dollars [14].

\section{RESEARCH METHODS}

\section{Time and Place of Research}

This research was conducted from December 2018 to March 2019, starting off the preparation of proposals, data collecting and data processing. Data processing was carried out at the Advanced Computer Laboratory, Faculty of Mathematics and Natural Sciences, Sam Ratulangi University, Manado.

\section{Data Analysis}

The data used in this study are secondary data in the form of closing prices and the call and put option price of Netflix, Inc. and the United States risk-free interest rate which refers to the Treasury Bill Rate. Secondary data was obtained from the website http://finance.yahoo.com and http://treasury.gov. Data processing is done using mathematical software. The sources used are from books, scientific journals, and the internet. The steps of this study are:

1. Retrieving data on closing prices and stock options for Netflix, Inc.

2. Calculating stock price returns by referring to formula (3).

3. Calculating stock price volatility along with standard errors by referring to equations (4) and (5).

4. Calculating the buy and sell option prices using the Black-Scholes model by referring to formulas (10), (11), (12) and (13).

5. Comparing the buy and sell option prices obtained in step 4 with the option price data obtained in step 1.

6. Drawing conclusions.

\section{RESULTS AND DISCUSSION}

\section{Data Description}

Daily closing price of stock data is used for the period of February 14, 2018 - January 31, 2019 taken from the Yahoo Finance website (http://finance.yahoo.com). This data is used to estimate stock price volatility. The amount of data taken follows the maturity of options.

The options to be calculated on theoretical prices are call options and put options issued by Netflix, Inc. with a maturity date of January 17, 2020, with the number of call options data is 81 , while the number of put options is 70 . This option data was taken on January 31, 2019. Therefore, the stock price as the initial stock price to calculate the option price is the closing price of the shares of Netflix, Inc. on January 31, 2019.

The risk-free interest rate used in this study is Treasury Bill Rates issued by the Government of the United States on January 31, 2019 with a maturity of 52 weeks, which is equal to $2.47 \%$. This data is retrieved from https://www.treasury.gov/resource-center/data-chart- center/interest-

rates/Pages/TextView.aspx?data=billrates.

\section{Calculating the Log Return Value}

Log Returns from Netflix, Inc. shares are calculated from the daily closing price of shares using equation (3). The results of the calculation are as follows:

For $t=1$,

$r_{t}=\ln \left(\frac{280,27}{266}\right)=0.0523$.

The calculation is repeated until it reaches $t=241$.

\section{Historical Stock Price Volatility Estimation Estimates}

Volatility estimate is calculated by referring to equation (4). The value of $\tau$ used is $1 / 252$. By using software, we obtain stock price volatility of 0.4676 . That is, uncertainty about the return given by Netflix, Inc. shares in the period February 14, 2018 to January 31, 2019 was $46.76 \%$. In other words, the higher the percentage volatility of a stock price, the more risky the stock is. Based on equation (5), the standard error in this estimation of volatility is $2.13 \%$.

\section{Calculating Theoretical Option Prices}

By using software, the theoretical price of call options and put options obtained on January 31, 2019 for the time due January 17, 2020 by using equations (32), (33), (34), and (35), including the following:

Table 1. Call Options Published by Netflix, Inc. on January 31, 2019 due on January 17, 2020

\begin{tabular}{|c|c|c|c|c|}
\hline $\begin{array}{c}\text { Contract } \\
\text { Name }\end{array}$ & $\begin{array}{l}\text { Strike } \\
\text { Price }\end{array}$ & $\begin{array}{c}\text { Option } \\
\text { Price }\end{array}$ & $\begin{array}{c}\text { Teorethical } \\
\text { Price }\end{array}$ & Decision \\
\hline \multicolumn{5}{|l|}{ NFLX200 } \\
\hline $\begin{array}{c}117 \text { Cooo } 9 \\
5000\end{array}$ & 95 & 248.32 & 246.7919 & Reconsider \\
\hline \multicolumn{5}{|l|}{$\begin{array}{c}5000 \\
\text { NFLX200 }\end{array}$} \\
\hline $\begin{array}{c}117 \text { Coo1o } \\
0000\end{array}$ & 100 & 230.5 & 241.9368 & Buy \\
\hline \multicolumn{5}{|l|}{ NFLX200 } \\
\hline $\begin{array}{c}117 \text { Coo1o } \\
5000\end{array}$ & 105 & 162.83 & 237.0914 & Buy \\
\hline \multicolumn{5}{|l|}{ NFLX200 } \\
\hline $\begin{array}{c}117 \text { Coo11 } \\
\text { OOOO }\end{array}$ & 110 & 241.25 & 232.2580 & Reconsider \\
\hline $\begin{array}{c}\text { NFLX200 } \\
\text { 117Coo115 } \\
\text { ooo }\end{array}$ & 115 & 138.6 & 227.4390 & Buy \\
\hline \multicolumn{5}{|l|}{ NFLX200 } \\
\hline $\begin{array}{c}117 \text { Coo12 } \\
\text { 000o }\end{array}$ & 120 & 218.53 & 222.6372 & Buy \\
\hline $\begin{array}{c}\text { NFLX200 } \\
117 \text { Coo12 } \\
5000\end{array}$ & 125 & 148.48 & 217.8554 & Buy \\
\hline \multicolumn{5}{|l|}{$\begin{array}{c}5000 \\
\text { NFLX200 }\end{array}$} \\
\hline $\begin{array}{c}117 \text { Coo13 } \\
\text { 0000 }\end{array}$ & 130 & 228.6 & 213.0967 & Reconsider \\
\hline $\begin{array}{c}\text { NFLX200 } \\
117 \text { Coo13 } \\
5000\end{array}$ & 135 & 214.7 & 208.3642 & Reconsider \\
\hline \multicolumn{5}{|l|}{ NFLX200 } \\
\hline $\begin{array}{c}117 \text { Coo14 } \\
\text { 0000 }\end{array}$ & 140 & 219.07 & 203.6611 & Reconsider \\
\hline
\end{tabular}

Based on the results obtained, the number of call options sold at prices below the theoretical price is 63. So, the proportion of the number of call options sold at prices below the theoretical price of the total number of call option is $63 / 81 \times 100 \%=77.7778 \%$. 
Table 2. Put Options Published by Netflix, Inc. on January 31, 2019 due on January 17, 2020

\begin{tabular}{|c|c|c|c|c|}
\hline $\begin{array}{c}\text { Contract } \\
\text { Name }\end{array}$ & $\begin{array}{l}\text { Strike } \\
\text { Price }\end{array}$ & $\begin{array}{c}\text { Option } \\
\text { Price }\end{array}$ & $\begin{array}{l}\text { Teorethical } \\
\text { Price }\end{array}$ & Decision \\
\hline \multicolumn{5}{|l|}{ NFLX200 } \\
\hline $\begin{array}{c}117 \text { Pooo9 } \\
5000\end{array}$ & 95 & 0.64 & 0.0557 & Reconsider \\
\hline \multicolumn{5}{|l|}{$\begin{array}{l}5000 \\
\text { NFLX200 }\end{array}$} \\
\hline $\begin{array}{c}117 \text { Poo10 } \\
0000\end{array}$ & 100 & 0.81 & 0.0829 & Reconsider \\
\hline \multicolumn{5}{|l|}{ NFLX200 } \\
\hline $\begin{array}{c}117 \text { Poo10 } \\
5000\end{array}$ & 105 & 1.35 & 0.1198 & Reconsider \\
\hline $\begin{array}{l}\text { NFLX200 } \\
\text { 117Poo11 }\end{array}$ & 110 & 1.38 & 0.1687 & Reconsider \\
\hline \multicolumn{5}{|l|}{ NFLX200 } \\
\hline $\begin{array}{c}117 \text { Poo115 } \\
\text { 000 }\end{array}$ & 115 & 1.43 & 0.2320 & Reconsider \\
\hline \multicolumn{5}{|l|}{ NFLX200 } \\
\hline $\begin{array}{c}\text { 117Poo12 } \\
\text { 0000 }\end{array}$ & 120 & 1.82 & 0.3126 & Reconsider \\
\hline \multicolumn{5}{|l|}{ NFLX200 } \\
\hline $\begin{array}{c}117 \text { Poo12 } \\
5000\end{array}$ & 125 & 1.91 & 0.4131 & Reconsider \\
\hline \multicolumn{5}{|l|}{$\begin{array}{c}5000 \\
\text { NFLX200 }\end{array}$} \\
\hline $\begin{array}{c}117 \text { Poo13 } \\
\text { 0000 }\end{array}$ & 130 & 2.03 & 0.5367 & Reconsider \\
\hline \multicolumn{5}{|l|}{ NFLX200 } \\
\hline $\begin{array}{c}117 \text { Poo13 } \\
5000\end{array}$ & 135 & 2.18 & 0.6865 & Reconsider \\
\hline \multicolumn{5}{|l|}{ NFLX200 } \\
\hline $\begin{array}{c}117 \text { Poo14 } \\
\text { 0000 }\end{array}$ & 140 & 2.7 & 0.8657 & Reconsider \\
\hline
\end{tabular}

Based on the results obtained, the number of put options sold at prices below the theoretical price is 27. So, the proportion of the number of put options sold at prices below the theoretical price of the total number of put options is $27 / 70 \times 100 \%=38.5714 \%$.

If the option price is lower than the theoretical price, it means that the option can be said to be underpriced (sold at a low price). So, the decision that should be taken is to buy the option. Whereas, if the option price is higher than the theoretical price, it means that the option can be said to be overpriced (sold at an expensive price). Therefore, it needs to be reconsidered.

\section{CONCLUSIONS AND SUGGESTIONS}

\section{Conclusions}

From the results of the research conducted, the following conclusions were obtained:

1. The proportion of the number of call options issued by Netflix, Inc. with the maturity date of January 17 , 2020 which is sold at prices below the theoretical price of the total number of call options is $77.7778 \%$.

2. Proportion of the number of put options issued by Netflix, Inc. with the maturity date of January 17, 2020 which is sold at prices below the theoretical price of the total number of put options is $38.5714 \%$.

\section{Suggestions}

Investors should keep the monitoring task on option price movements on the stock exchange in order to obtain the cheapest option price at the desired strike price.

\section{REFERENCES}

[1] Undang-Undang Nomor 8 Tahun 1995 tentang Pasar Modal. Lembaran Negara RI Tahun 1995 No. 64. Sekretariat Negara, Jakarta.

[2] Safitra A.D., R. Nugroho, dan Y. Irwanto. 2011. Stock Option. Seminar Pasar Modal. Sekolah
Tinggi Akuntansi Negara, Tangerang.

[3] Seleky, J.S. 2012. Penentuan Nilai Opsi Call Barrier Dengan Dividen Tunggal di Bursa Efek Indonesia [thesis]. FMIPA IPB, Bogor.

[4] Baxter, M., dan Rennie, A. 1996. Financial Calculus an Introduction to Derivative Pricing. Cambridge University Press, Cambridge.

[5] Hull, J.C. 2009. Options, Futures, and Other Derivative Securities. Seventh Edition. Prentice Hall, New Jersey.

[6] Gustyana, T.T. 2014. Analisis Perbandingan Keakuratan Harga Call Option dengan Menggunakan Metode Monte Carlo Simulation dan Metode Black Scholes pada Indeks Harga Saham Gabungan (IHSG). Jurnal Manajemen Indonesia. 14(3): 259-268.

[7] Pramuditya, S.A. 2016. Perbandingan Metode Binomial dan Metode Black-Scholes Dalam Penentuan Harga Opsi. Jurnal Sainsmat. 5(1): 16.

[8] McDonald, R.L. 2006. Derivatives Markets. Second Edition. Pearson Education, Boston.

[9] Bursa Efek Indonesia. 2010. Derivatif. http://www.idx.co.id/idid/beranda/produkdanlayanan/derivatif.aspx [2 Desember 2018].

[10] Luenberger, D.G. 1998. Investment Science. Oxford University Press, New York.

[11] Karnadjaja, A., E. Ong, C. Wijaya, B. Tanujaya, dan J. Effendi. 2007. Smart Investment for Mega Profit. Elex Media Komputindo, Jakarta.

[12] Bittman, J.B. 2009. Tingkatkan Profit Melalui Opsi. Terjemahan Rayendra L.T. Elex Media Komputindo, Jakarta.

[13] Ruppert, D. 2011. Statistics and Data Analysis for Financial Engineering. Springer, New York.

[14] https://www.netflixinvestor.com/iroverview/profile/default.aspx [26 Maret 2019].

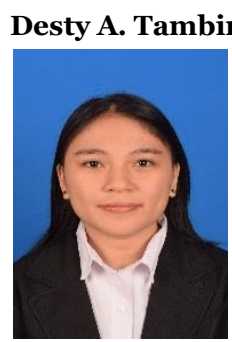

gon (destytambingon@gmail.com) Was born in Jakarta on Desember 7 1997. Took her undergraduate program in Mathematics Department, Faculty of Mathematics and Natural Sciences, Universitas Sam Ratulangi Manado. 2019 is the last year she pursued her undergraduate program. This paper is her published research.

Jullia Titaley (july_titaley@unsrat.ac.id)

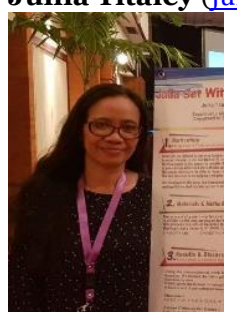

In 1997, she got her bachelor degree in Mathematics Department, Universitas Pattimura Ambon. She got her Master of Science from Universitas Gajah Mada in 2001. Being a lecturer in Mathematics Department, Universitas Sam Ratulangi Manado since 2002 until now with areas of expertise including Analysis, Algebra, and

Geometry. 
Black-Scholes Model in Determining European Option Prices on Netflix,Inc.

d'Cartesian : Jurnal Matematika dan Aplikasi, Vol. 8 No. 2 (September 2019): 80-85

Tohap Manurung (tohapm@unsrat.ac.id)

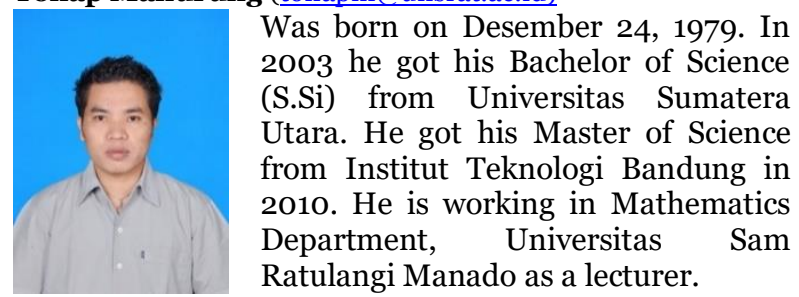

Was born on Desember 24, 1979. In

2003 he got his Bachelor of Science

from Universitas Sumatera

Ratulangi Manado as a lecturer. 